\title{
Interactions of Actinophage and Clays
}

\author{
By I. K. SYKES AND S. T. WILLIAMS \\ Botany Department, University of Liverpool, Liverpool L69 $3 B X$
}

(Received 31 March 1978; revised 2 May 1978)

Over $60 \%$ of streptomycete phage, isolated from soil, were adsorbed by unsubstituted or sodium-treated kaolin, when suspended in nutrient broth, but less phage were adsorbed by sodium and calcium montmorillonite or by calcium- and aluminium-treated kaolin. The montmorillonites did, however, partially protect one of the phage from damage during experimental manipulations. Adsorption to kaolin was not influenced by $\mathrm{pH}$ and most of the adsorbed phage retained their infectivity. Attempts to obtain free infectious phage by desorption were unsuccessful. The $\mathrm{pH}$ stabilities of adsorbed and free phage differed: $50 \%$ inactivation of phage adsorbed to kaolin occurred at $\mathrm{pH} 6 \cdot 1$ whereas for free phage $50 \%$ inactivation occurred at $\mathrm{pH} 4.9$. This suggested that $\Delta \mathrm{pH}\left(\mathrm{pH}_{\mathrm{b}}-\mathrm{pH}_{\mathrm{s}}\right)$ was about 1.2 units, i.e. similar to previous estimates based on the activity of enzymes adsorbed to kaolin.

\section{INTRODUCTION}

Most studies of phage have been made in laboratory cultures and little is known of their behaviour or significance in natural habitats. Phage are usually readily isolated from soil, although their titres are often very low (Casida \& Liu, 1974; Tan \& Reanney, 1975). The genus Streptomyces is widespread in soil and phage attacking these actinomycetes are similarly distributed. It is not easy to simulate conditions in soil but the presence of solid surfaces is an obvious and important difference between the soil environment and broth cultures. Clay minerals and other surface-active particles can adsorb or coat microbial cells (Marshall, 1968, 1969), enhance microbial growth (Stotzky \& Rem, 1966) and influence enzyme activity (Skujins et al., 1974). Although phage may be adsorbed to a variety of surfaces, there is little information on their interaction with clays.

In a recent study, Bystricky et al. (1975) used electron microscopy to demonstrate adsorption of phage to kaolinite. In the investigation reported here, the interactions of streptomycete phage with a range of clay minerals were studied, and the effects of clays on certain properties of the phage particles were assessed.

\section{METHODS}

Clays. The three clays used were light kaolin (Hopkin \& Williams), calcium montmorillonite (B.D.H.) and sodium montmorillonite (B.D.H.). Homoionic clays were prepared by washing a known weight of clay three times in a solution of either $0.5 \mathrm{M}-\mathrm{NaCl}, 0.25 \mathrm{M}-\mathrm{CaCl}_{2}$ or $0.17 \mathrm{M}-\mathrm{AlCl}_{3}$. The sample was then washed with distilled water until the supernatant was free of chloride. The treated clay was centrifuged to a thick slurry and stored at $4{ }^{\circ} \mathrm{C}$.

Adsorption of phage. The two phage used were designated $\mathrm{f} 6$ and $\mathrm{f} 13$. They were isolated from soil and propagated on two soil isolates classified as Streptomyces F6 and Streptomyces F13. Samples of unsubstituted or homoionized clay were added to flasks of nutrient broth (Oxoid CM1) to give concentrations of 0.001 to $200 \mathrm{mg} \mathrm{ml}^{-1}$. An accurately titrated phage suspension was added to the flasks to give a titre of $10^{6}$ plaqueforming units (p.f.u.) $\mathrm{ml}^{-1}$. The flasks were incubated at $25^{\circ} \mathrm{C}$ on an orbital shaker at $200 \mathrm{rev}$. $\mathrm{min}^{-1}$ and 


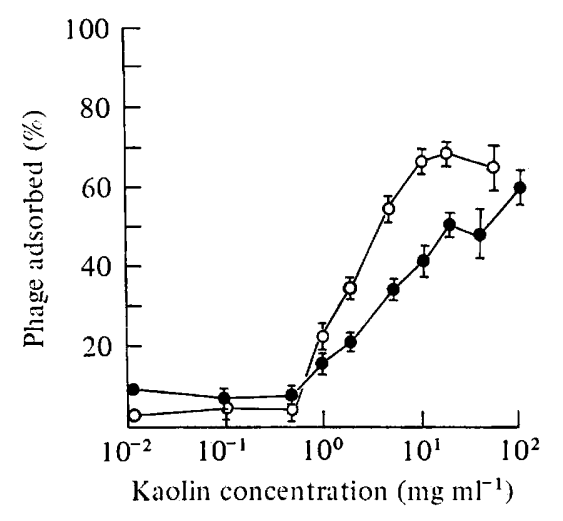

Fig. 1

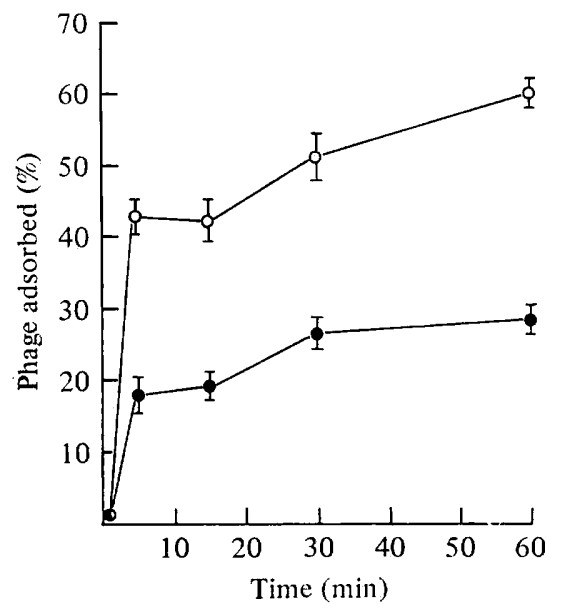

Fig. 2

Fig. 1. Adsorption of phage f6 $(\Theta)$ and $\mathrm{f} 13(\mathrm{O})$ by kaolin in nutrient broth at $25^{\circ} \mathrm{C}$. Standard errors of the mean of three replicates are shown.

Fig. 2. Time course of adsorption of phage $\mathrm{f} 6$ by kaolin at $2 \mathrm{mg} \mathrm{ml}^{-1}(\odot)$ and $20 \mathrm{mg} \mathrm{ml}^{-1}(\bigcirc)$ in nutrient broth at $25^{\circ} \mathrm{C}$.

samples were removed at intervals. These were centrifuged at $2000 \mathrm{~g}$ for $5 \mathrm{~min}$ at room temperature and then passed through a cellulose acetate filter (pore size $0 \cdot 45 \mu \mathrm{m}$ ). Free phage were counted by the double layer method. Serial 10-fold dilutions were prepared and $0.1 \mathrm{ml}$ samples were pipetted on to a base layer of nutrient agar (Oxoid, CM3) supplemented with $0.5 \%(\mathrm{w} / \mathrm{v})$ glucose and $4 \mathrm{~mm}-\mathrm{Ca}\left(\mathrm{NO}_{3}\right)_{2}$. These plates were overlaid with $2.5 \mathrm{ml}$ of soft agar $(0.8 \%, \mathrm{w} / \mathrm{v})$ at $46^{\circ} \mathrm{C}$ seeded with the host spore suspension. Plaques were counted after $18 \mathrm{~h}$ at $25^{\circ} \mathrm{C}$. All counts were expressed as a proportion of the titre in control flasks without clay.

Infectivity and $\mathrm{pH}$ stability of adsorbed phage. Whole sample counts were made to determine the infectivity

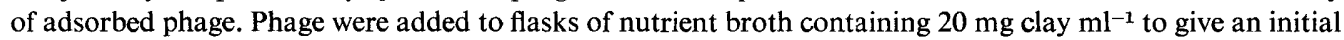
concentration of $10^{3}$ p.f.u. $\mathrm{ml}^{-1}$. Samples were removed at intervals and assayed directly for phage.

The effect of $\mathrm{pH}$ on phage stability was assessed in a similar manner, the adsorption mixtures being adjusted with $0 \cdot 1 \mathrm{M}-\mathrm{HCl}$ or $0 \cdot 1 \mathrm{M}-\mathrm{NaOH}$ to cover a range from $\mathrm{pH} 3.5$ to $10 \cdot 0$. Phage were assayed after $10 \mathrm{~min}$ in the flask mixtures.

Desorption of phage. Numbers of phage adsorbed on clay at $20 \mathrm{mg} \mathrm{ml}^{-1}$ were determined by difference from the numbers of free phage in the supernatant. The clay with attached phage was resuspended in $10 \mathrm{ml}$ nutrient broth, agitated for $1 \mathrm{~min}$ and centrifuged. The supernatant was assayed for phage and the clay pellet was resuspended. After several such cycles, the pellet itself was finally plated out for phage assay. Phage suspension in nutrient broth without kaolin was treated and assayed in the same manner.

\section{RESULTS}

\section{Adsorption of phage}

Both phage were apparently adsorbed by kaolin, with a maximum removal of $65 \%$ of $\mathrm{f} 6$ and $75 \%$ of $\mathrm{f} 13$ (Fig. 1). Adsorption values were calculated as a proportion of counts in control flasks without clay; phage $\mathrm{f} 13$ was sensitive to experimental manipulation, up to $65 \%$ being inactivated in the control flasks. No significant adsorption occurred at clay concentrations below about $1 \mathrm{mg} \mathrm{ml}^{-1}$. Adsorption increased steadily above this concentration, levelling off between 10 and $20 \mathrm{mg} \mathrm{ml}^{-1}$.

The effect of varying phage concentrations on adsorption was studied using $\mathrm{f} 6$ with $20 \mathrm{mg}$ kaolin $\mathrm{ml}^{-1}$. A constant proportion of phage (50 to $60 \%$ ) was adsorbed throughout the concentration range tested. The adsorption of phage $\mathrm{f} 6$ by kaolin at $20 \mathrm{mg} \mathrm{ml}^{-1}$ was also tested at different $\mathrm{pH}$ values. Within the limits of phage stability ( $\mathrm{pH} 6.5$ to 8.5 ), adsorption was unaffected. 


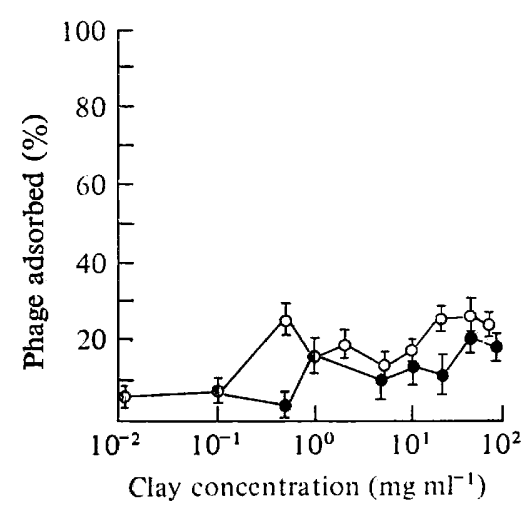

Fig. 3

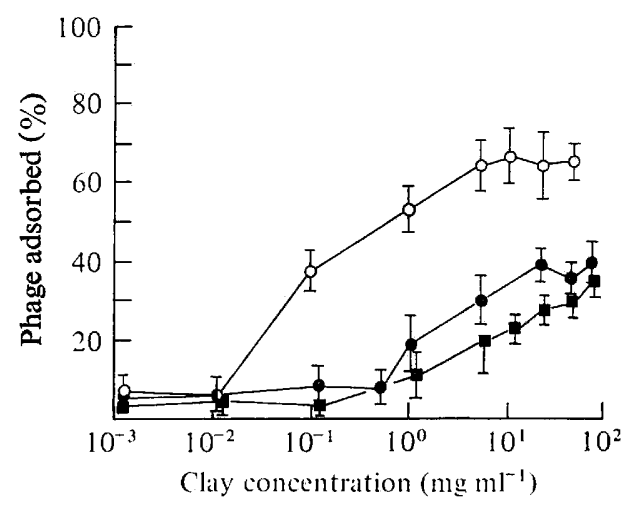

Fig. 4

Fig. 3. Adsorption of phage $\mathrm{f} 6$ by sodium montmorillonite $(\mathrm{O})$ and calcium montmorillonite in nutrient broth at $25^{\circ} \mathrm{C}$.

Fig. 4. Adsorption of phage $\mathrm{f} 6$ by sodium kaolin $(\bigcirc)$, calcium kaolin ( $)$ and aluminium kaolin

(a) in nutrient broth at $25^{\circ} \mathrm{C}$.

Adsorption of phage $\mathrm{f} 6$ by kaolin at 2 and $20 \mathrm{mg} \mathrm{ml}^{-1}$ was tested after different times (Fig. 2). Little change in numbers of adsorbed phage occurred after $5 \mathrm{~min}$ at either concentration.

The montmorillonites were less effective in removing phage from suspension. Sodium montmorillonite adsorbed 25 to $30 \%$ of phage $\mathrm{f} 6$ at equilibrium, while calcium montmorillonite removed $20 \%$ (Fig. 3). Little adsorption of phage 113 occurred with these clays, but increasing concentrations of clay decreased the losses due to the sensitivity of this phage to the experimental procedures.

Adsorption of phage $\mathrm{f} 6$ to kaolin treated with $\mathrm{Na}^{+}, \mathrm{Ca}^{2+}$ and $\mathrm{Al}^{3+}$ ions was investigated (Fig. 4). Sodium kaolin proved to be a more efficient adsorbent than the unsubstituted kaolin, with as little as $0.1 \mathrm{mg} \mathrm{ml}^{-1}$ adsorbing significant proportions of the phage. Maximum adsorption again removed about $60 \%$ of the phage, but this occurred at lower clay concentrations ( 5 to $10 \mathrm{mg} \mathrm{ml}^{-1}$ ). Adsorption by calcium and aluminium kaolin was less than with the unsubstituted clay, the maximum removal being 35 to $40 \%$ with no significant adsorption below $1 \mathrm{mg} \mathrm{ml}^{-1}$.

\section{Infectivity of adsorbed phage}

The efficiencies of plating of phage $\mathrm{f} 6$ mixed with $20 \mathrm{mg}$ kaolin $\mathrm{ml}^{-1}$ and with the same concentration of calcium montmorillonite were compared with that in broth without clay. With the poor adsorbent, calcium montmorillonite, the mean loss was $6 \cdot 14 \pm$ S.E.M. $1 \cdot 75 \%$. This was not significantly higher than that in broth without clay $(4 \cdot 80 \pm 0.93 \%)$. The loss with kaolin $(9 \cdot 74 \pm 1 \cdot 60 \%)$ was significantly higher than that obtained with calcium montmorillonite or the control. However, as the percentage loss was much less than the percentage adsorption $(60 \%)$, it was concluded that the majority of adsorbed phage were still infective.

\section{Desorption of phage}

The centrifugation-washing procedure resulted in the recovery of only 1 to $2 \%$ of the adsorbed phage (Table 1). Furthermore, plating of the final clay pellet after washing produced few or no plaques. Similar treatment of the control broth resulted in recovery of about $80 \%$ of the phage. 
Table 1. Desorption of phage $\mathrm{f} 6$ adsorbed by kaolin $\left(20 \mathrm{mg} \mathrm{ml}^{-1}\right)$ (expressed as p.f.u.)

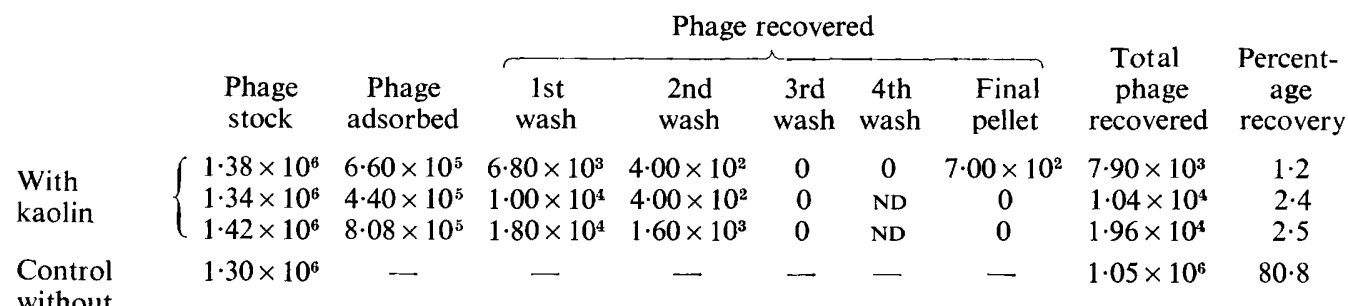

without

kaolin

ND, Not determined.

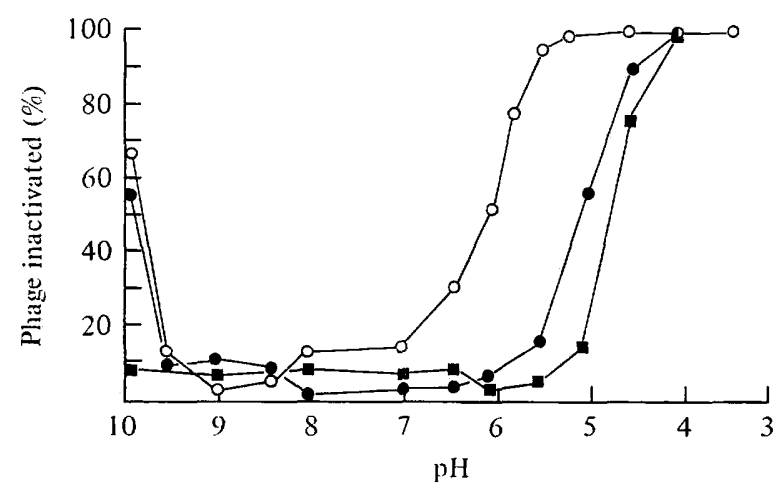

Fig. 5. Effect of $\mathrm{pH}$ on the stability of phage $\mathrm{f} 6$ with $20 \mathrm{mg} \mathrm{kaolin} \mathrm{ml}^{-1}(\mathrm{O}), 20 \mathrm{mg}$ calcium montmorillonite $\mathrm{ml}^{-1}(\boldsymbol{D})$ and without clay (O) in nutrient broth at $25^{\circ} \mathrm{C}$.

\section{Effect of clay on pH stability of phage}

The $\mathrm{pH}$ stabilities of phage $\mathrm{f} 6$ after $10 \mathrm{~min}$ in the presence of kaolin, calcium montmorillonite and in broth without clay were compared (Fig. 5). In nutrient broth, the limits of phage stability were $\mathrm{pH} 9 \cdot 5$ to $\mathrm{pH} 5 \cdot 5$ and $50 \%$ inactivation $\left(\mathrm{ID}_{50}\right)$ occurred at $\mathrm{pH} 4 \cdot 9$. With calcium montmorillonite, the limits were extended to $\mathrm{pH} 10 \cdot 0$ to $\mathrm{pH} 5 \cdot 3$ and the $\mathrm{ID}_{50}$ was at $\mathrm{pH} 4.8$. In contrast, the phage stability range with kaolin was reduced to $\mathrm{pH} 9 \cdot 5$ to $\mathrm{pH} 7 \cdot 0$ and the $\mathrm{ID}_{50}$ was at $\mathrm{pH} 6 \cdot 1$. In all cases, total phage inactivation occurred after $10 \mathrm{~min}$ at $\mathrm{pH} 4 \cdot 0$.

\section{DISCUSSION}

Kaolin adsorbed more phage than montmorillonite and adsorption to the former was greater when it was unsubstituted or homoionized with $\mathrm{Na}^{+}$than when it was treated with $\mathrm{Ca}^{2+}$ or $\mathrm{Al}^{3+}$. As the experiments were carried out in nutrient broth which contains $0.5 \%$ $(\mathrm{w} / \mathrm{v}) \mathrm{NaCl}$, 'unsubstituted' kaolin presumably contained the sodium form. Our results only partially agree with those of Bystricky et al. (1975) who reported strong adsorption of phage and other viruses to kaolinite and montmorillonite.

Both clay and phage particles carry a net negative charge under most conditions. Adsorption of negatively charged microbial cells to clays and other surfaces depends on the presence, concentration and valency of associated cations. Zvyagintsev (1962) suggested that adsorption of bacteria to negatively charged resins depended on cation valency and saturation. Adsorption of actinomycete spores to anion exchange resins and montmorillonite was greatest in the presence of polyvalent cations (Ruddick \& Williams, 1972). Similarly, Stotzky \& Bystricky (1969) found that adsorption of bacteria in clays homoionic to $\mathrm{Al}^{3+}$ was greater than in those saturated with $\mathrm{Na}^{+}$. However, our results with actinophage and 
homoionized kaolin suggest that interactions between clay-phage surfaces and cations do not provide an explanation for adsorption.

Different degrees of adsorption of microbial cells to kaolin and montmorillonite have been reported. Streptomycete spores were strongly adsorbed by kaolin over a wide $\mathrm{pH}$ range but adsorption to montmorillonite was slight above $\mathrm{pH} 4$ (Ruddick \& Williams, 1972). A similar effect was obtained with Bacillus cells by Santaro \& Stotzky (1968) who suggested that the difference could be due to the greater number of positively charged edge sites on kaolinite compared with montmorillonite (Van Olphen, 1963). Our results indicate that direct attachment of phage particles to positively charged edge sites on the clays is a possible mechanism of adsorption.

Adsorption of phage to kaolin was rapid and, like that of streptomycete spores (Ruddick $\&$ Williams, 1972), was unaffected by $\mathrm{pH}$. Most of the adsorbed phage retained their infectivity, as did the viruses studied by Bystricky et al. (1975). At kaolin concentrations of $20 \mathrm{mg} \mathrm{ml}^{-1}$ and above, a fixed proportion of the phage was adsorbed irrespective of the concentration of phage particles. This was possibly due to heterogeneity in the surface properties of the phage population. Interestingly, populations of Bacillus subtilis mixed with clay colloids contained both adsorbing and non-adsorbing cells (Lahav, 1962). Phage f13, which was quite sensitive to the experimental procedures, was progressively protected by increasing concentrations of montmorillonites, although little adsorption occurred. The phage was presumably protected against factors such as increased temperature or mechanical damage during the experimental procedure.

Results of the desorption experiments were surprising. Although washing removed only 1 to $2 \%$ of the adsorbed phage, little or no plaques resulted when the clay pellet was plated out. As previously mentioned, direct plating of clay-phage mixtures indicated that most adsorbed phage were still infective. Therefore, it is possible that either the process of desorption or the successive suspension and centrifugation in the presence of clay led to inactivation of the phage.

Clay particles are strongly electronegative and therefore, in an aqueous phase, they require a cloud of cations, including hydrogen ions, for overall neutrality. This results in a difference $(\Delta \mathrm{pH})$ between the $\mathrm{pH}$ at or near the particle surface $\left(\mathrm{pH}_{\mathrm{s}}\right)$ and that in the bulk phage $\left(\mathrm{pH}_{\mathrm{b}}\right)$ which is usually higher. $\mathrm{pH}$ cannot be measured directly but can be estimated in a number of ways. One method is to compare the $\mathrm{pH}$ optimum of an enzyme in the presence of clay particles with that in a solution without clay, the difference representing the approximate $\Delta \mathrm{pH}$ (McLaren \& Skujins, 1968). The $\mathrm{pH}$ optimum for activity of chymotrypsin was about 2 units higher when adsorbed to kaolin than when in solution (McLaren \& Estermann, 1957). Similar results have been reported for other enzymes, including phosphatase (Ramirez \& McLaren, 1966) and chitinase (Skujins et al., 1974). Comparison of the $\mathrm{pH}$ stability of phage $\mathrm{f} 6$ in broth, in the presence of a poor adsorbent and a strong adsorbent (kaolin) also provides an estimation of $\Delta \mathrm{pH}$. The $\mathrm{ID}_{50}$ values in broth and calcium montmorillonite were at $\mathrm{pH} 4.9$ and $\mathrm{pH} 4.8$, respectively. However with kaolin the $\mathrm{ID}_{50}$ was at $\mathrm{pH} 6 \cdot 1$, suggesting that $\mathrm{pH}_{\mathrm{s}}$ encountered by adsorbed phage was about $1 \cdot 2$ units lower than $\mathrm{pH}_{\mathrm{b}}$. Thus phage stability, like enzyme activity, can be used as a 'molecular pH meter' (McLaren, 1975). $\Delta \mathrm{pH}$ for kaolin with chymotrypsin was $2 \cdot 0$ (McLaren \& Estermann, 1957) and with chitinase was $1 \cdot 2$ (Skujins et al., 1974). The results also supported the conciusion that many of the phage particles were in close association with kaolin particles.

Soil colloids may therefore have a major influence on phage in soil. Adsorbed phage can remain infective, possibly be protected and be in close proximity to host spores which can also be adsorbed. On the other hand, adsorbed phage will be more susceptible to inactivation by low $\mathrm{pH}$ in moderately acidic soils. 


\section{REFERENCES}

Bystricky, V., Stotzky, G. \& Schiffenbauer, M. (1975). Electron microscopy of T1 bacteriophage adsorbed to clay minerals: application of the critical point drying method. Canadian Journal of Microbiology 21, 1278-1282.

CAsida, L. E. \& LIU, W. (1974). Arthrobacter globiformis and its bacteriophage in soil. Applied Microbiology 28, 951-959.

LaHAV, N. (1962). Adsorption of sodium bentonite particles on Bacillus subtilis. Plant and Soil 17, 191-208.

MARSHALL, K. C. (1968). Interaction between colloidal montmorillonite and cells of Rhizobium spp. with different ionogenic surfaces. Biochimica et biophysica acta 156, 179-186.

Marshall, K. C. (1969). Studies by microelectrophoretic and microscopic techniques of the sorption of illite and montmorillonite to rhizobia. Journal of General Microbiology 56, 301-306.

McLaren, A. D. (1975). Soil as a system of humus and clay immobilized enzymes. Chemica scripta $\mathbf{8}$, 97-99.

MClaren, A. D. \& Estermann, E. F. (1957). Influence of $\mathrm{pH}$ on the activity of chymotrypsin at a liquid solid interface. Archives of Biochemistry and Biophysics 68, 157-160.

Mclaren, A. D. \& Skujins, J. J. (1968). The physical environment of micro-organisms in soil. In The Ecology of Soil Bacteria, pp. 3-24. Edited by T. R. G. Gray \& D. Parkinson. Liverpool: Liverpool University Press.

Ramirez, J. R. \& MCLAREN, A. D. (1966).
Factors influencing phosphatase in soils. Enzymologia 31, 23-38.

RudDick, S. M. \& Williams, S. T. (1972). Studies on the ecology of actinomycetes in soil. V. Some factors influencing the dispersal and adsorption of spores in soil. Soil Biology and Biochemistry 4, 93-103.

Santaro, T. \& Stotzky, G. (1968). Sorption between microorganisms and clay minerals as determined by the electrical sensing zone particle analyzer. Canadian Journal of Microbiology 14, 299-307.

Skujins, J., Pukite, A. \& Mclaren, A. D. (1974). Adsorption and activity of chitinase on kaolinite. Soil Biology and Biochemistry 6, 179-182.

Stotzky, G. \& Bystricky, V. (1969). Electron microscopic observation of surface interactions between clay minerals and microorganisms. Bacteriological Proceedings, A93.

StotZKy, G. \& REM, L. T. (1966). Influence of clay minerals on microorganisms. I. Montmorillonite and kaolinite on bacteria. Canadian Journal of Microbiology 12, 547-563.

TAN, J. S. H. \& REANNEY, D. C. (1975). Interactions between bacteriophages and bacteria in soil. Soil Biology and Biochemistry 8, 145-150.

VAN OlPHEN, H. (1963). An Introduction to Clay Colloid Chemistry. New York: Interscience.

ZVYAGINTSEV, D. G. (1962). Some principles of the adsorption of micro-organisms on ion exchange resins. Microbiology (English translation) 31, 339-343. 